\title{
スルファターゼ模型に關する研究 (其八)
}

(昭和十七位三月井日受領)

$$
\text { 江上不二夫 }
$$

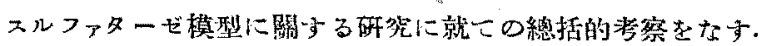

\section{［I] 緒論}

硫酸ェステルは種々な形で廣く動植物界に分布してるる.師ち，(1）フェノ一ル類の硫酸ェステル は殆ど凡ての動物に見出される．尿インデカンと呼ばれてるるインドキジル硫酸を始め，エス下ロン

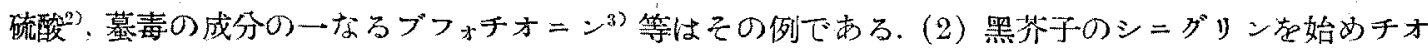
グルンシドの硫酸ェステルが種々の植物種子中に見出された. (3) 炭水化物の硫酸ェステルとしては，

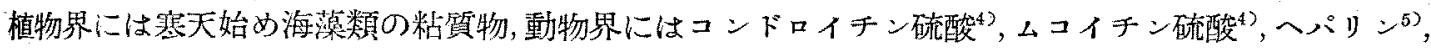
カロニン硫酸6)，七レブロン硫酸”等が知られてるる。（4）其の他，Hammarsten はコレステリン樣

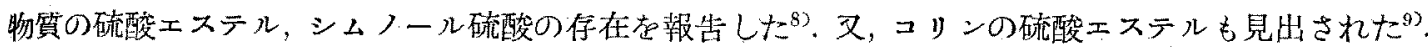

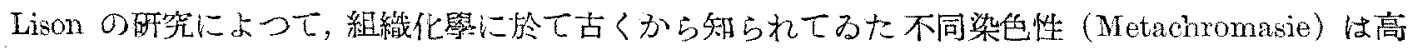
分子硫酸エステルに依ることが明かになつだ゚. それにより，殆に゙凡ての細胞が多少の硫酸エステル 灰含有することが示された，從つて，硫酸ェステルは種々の重要な牛理的意義老有するものと想像さ れる.その點に閵しては，未だ十分は研究がなされてるないが，既に，これ等の硫酸エステルを

$$
\mathrm{R}-\mathrm{OSO}_{3} \mathrm{Na}+\mathrm{H}_{2} \mathrm{O} \rightarrow \mathrm{R}-\mathrm{OH}+\mathrm{NaHSO}_{4}
$$

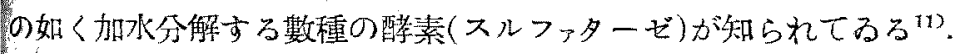

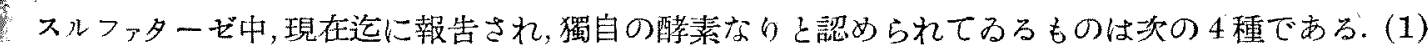
ミロスルファターゼ:シニダリン等分分解し,茶子の種子中にある. (2) フェノールスルファターゼ:フェ ノール類の碳酸エステル在分解する．高等動物在始め多くの動物の臟器中にあり，叉，夕カデアスタ 一ゼ中にも存する.（3）コンドロスルファターゼ:コンドロイチン硫酸，ムコイチン硫酸等㾟分解する。 最初、或種の細菌中に見出されたが，ての後，多くの乾體動物中に見出され，最近は漓等動物にも僅か に認められた. (4) グルコスルファターゼ くの軟能量物中に見出されたが，バウシウホラの肝臟はその特によい材料である，佾，僅かには或種 の細菌，高等動物にも認められた。

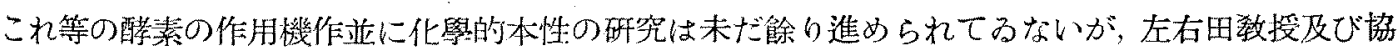

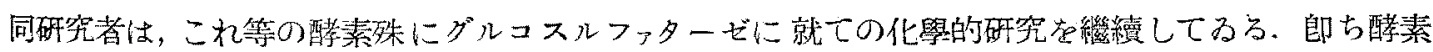

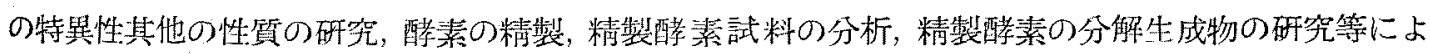
りスルファターゼの化學的本性に關する知見が得られつ・ある.

笋者はスルファターゼの本性，作用機作等然和るには：この㥞な研究方法の他に，W．Langenbeck

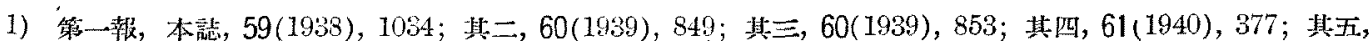
$61(1940), 692$; 其穴, $61(1940), 855$; 其七, 62(1941), 274. 2) A. Butenandt, H. Hofstetter: Z. physiol. Chen., 259(1939), 222. 3) H. Wieland, T. Wieland: Ann., 528(1937), 234. 4) P. A. Levene: "Hexosamines and Mucoproteins," (1922). 5) E. Jorpes, S. Bergström: Z. physiol. Chem., 244(1936), 253. 6) 左右日, 江上: Bull. Chem. Soc. Japan, 13(1938), 652; 本䙵, 59(1938), 1417. 7) G. Blix: Z. physiol. Chem., 219(1935), 82. 8) O. Hammarsten: Z. physiol. Chem., 24(1897), 322. 9) D. W. Woolley, W. H. Peterson: J. Biol. Chem., 122(1987), 213. 10) L. Lison: Bull. soc. chim. biol., 18(1936),

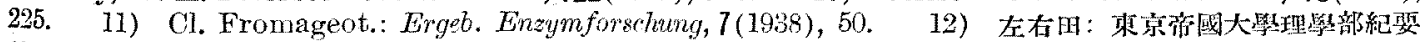

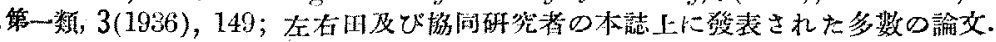


が爲してるる如き酵素模型によろ研究も笴與するであらうと考人て本研究に着手したのである。

W. Langenbeck は諸㮔の触媒機能を有方有機化合物の研究を行ひ，その中數種のものは酵素類 似の作用を有することを見出した ${ }^{13)}$. それ等を酵素模型 (Fermentmodelle) と見做し，酵素模型の研 究は酵素の作用基の本質を暗示するものであると主張してるる. Langenbeck は既に，カルボキシラ 一ゼ模型，エステラーゼ模型其他多くの酵素模型在見出したが，一例としてカルボキシラーゼ模型に 就き簡單に迅べれば， $\alpha$-ケト酸に作用して炭酸を遊離せしめる酵素模型としては多くの第一級アミン が有効である. 然して，その作用機作は，Langenbeck によれば次の如くである.

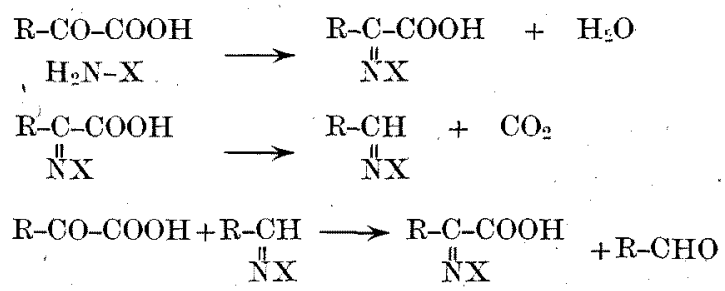

Langenbeck は， $\omega$-オキシアセトフェノン-4-ーカルボン酸がェチル硫酸，フェテル硫酸の分解存促進 することを認めてるるが；それは硫酸エステルに限らす酪酸メチチル其他一般のェステルに作用するか らスルファターゼの作用機作を暗示するものとも思はれず, 及, 硫酸エステルの研究に寄與するとも思 はれない，それ故，筆者はこれ以外の物質に於てグルコスルファターゼの被解質なるダルコーゼ硫酸 の分解を促進する觸媒を檢索した。

その检索に依うてヒドラデン及び或種のその誘導體がグルコーゼ硫酸の分解を促進する觸媒なる こと,トリパフラヴィン,リヴァノールが或種の硫酸エステルと結合沈澱し，且つ，その浓澱反應の特巽 性がスルファターゼの特異性と一致すること等見出した. それ故, 前者はダルコスルファターぞ模型,

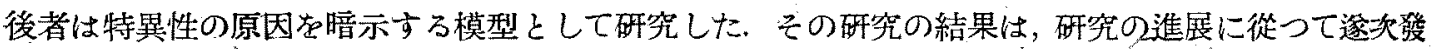
表したが, 出にその總括的考察をしたいと思ふ.

\section{[II ] ヒドラヂン及びその誘導體による硫酸エステルの加水分解}

ヒドラヂシ及び或種のその有機誘導體，金屬錯監は中性又は弱酸性でグルコーゼ硫酸に作用し硫酸 基を離脫せしめる(第一報)、その觸媒作用を有する爲には，ヒドラヂンの少くとも一つのアミつ基は 遊離してるなければならない. 郎ち， $\mathrm{H}_{2} \mathrm{~N} \cdot \mathrm{NHR}, \mathrm{H}_{2} \mathrm{~N} \cdot \mathrm{NRR}$ は有効であるが， $\mathrm{RHN} \cdot \mathrm{NHR}$ は無効 である(其四). ヒドラヂン性反應中に減少しない事を沃素酸により滴定する方法で確めた，從つてヒ

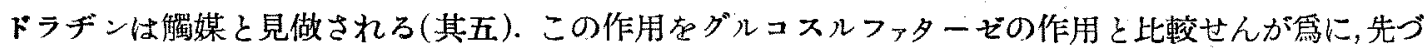
$p \mathrm{H}$ の影響, 特異性を檢した. 最適 $p \mathrm{H}$ は 5 附近にあり,ダルコスルファターゼのそれと完全に一致し た(第一報). 特異性に閣してはダルコーゼ硫酸, フルクトーゼ硫酸を分解し, ェチル硫酸, フェニル硫 酸, 、ンニット硫酸,コンドロイチン硫酸を分解しない事を最初に認めた(第一報)ので,グルコスルフォ ターゼの特異性とよく一致すると思はれたが，之の後更に檢索の範園を廣げるに及び必ずしも一致し ない事が認められた，郎ち，(1) ヒドラヂンにより分解される爲には還元基が遊離してるなくてはな らない. 還元性を持たない よく分解されろが，ヒドラヂンによつては分解されない(其四).（2）アルドへキンーゼの 6-位置にあ ろ硫酸基はヒドラチンにより認められる程の分解在示さない.この點はグルコスルファターゼと殊に 異万點である。簡易化された合成法に從つて調製したグルコーゼモノ硫酸14)にヒドラヂンを作用せし

13) W. Langenbeck: "Die organischen Katalysatoren und ihre Beziehungen zu den Fermenten," Berlin, (1935). 14) 左右田: Bull. Chem. Soc. Japan, 8(1933), 37. 
めると約 $15 \%$ で分解が停止するが，それは大部分の硫酸基が 6 -位置にある爲である ${ }^{15)}$ (其五).グル コーゼ硫酸をブルシン監として分別結晶せしめ, 純粹にダルコーゼ-6-モ)硫酸としたものは殆と分解 されない6．これに反し，同樣にして調撆されたガラクトーゼモノ硫酸は硫酸基が 6-位置になく，ラ カトル環中にある䉆にヒドラヂンによりよく分解される. ${ }^{16)}$ ペントーゼ硫酸がよく分解される(其四) のも同樣な理由により說明される.（3）アルドール硫酸はヒドラデンによりよく分解される(其七). 從つて還元基があれば必ずしも糖類硫酸エステルでなくても分解される事がわかろ：この點もグルコ スルファターゼと晎る。

ダルコスルファターゼによる分解が㱠ど零次反應なるに反し，ヒドラデンによる分解は一般に初期 に於て反隹速度が大で，それ以後速に減ずる傾向がある。糖類硫酸エステルは構造の確定した均一な もの得ることが、般に困難な爲に多くの場合種々の硫酸ェステルの混合物を用ふるから，ヒドラチ ンによろ分解を反應速度論的に解析することは一般に困難である. 併し, 硫酸基が只一箇所以外に附 き得ないアルドール硫酸の場合には，ほぶ一次反應に從ふことが認められた(其七). 又,アラピノ一 ゼ硫酸の分解に就ての實驗で, 反應速度はヒドラヂンの濃度に比例すること, $20^{\circ} \sim 30^{\circ}$ の溫度係數は 、的 2.5 なることが認められた(其七).

グルコスルファターゼに特異的に妨害又は促進作用を有する諸程煻類, 燐酸監, シアン化物, 重金屬

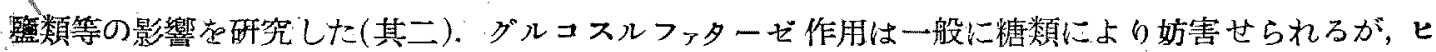
ドラヂンに對しては大なる影響はない、併し，グルコーゼの如く明かに促進作用を有するものもある (其二). 燐酸鹽、シアン化物はグルコスルファターゼには强い妨害作用有するが, ヒドラヂンの作用

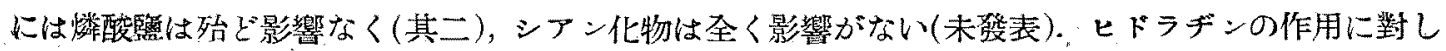

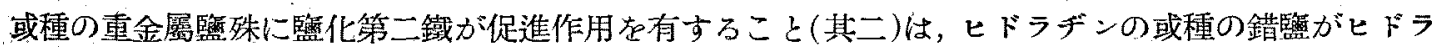
ヂン自身よりも强力な觸媒なる事實(第一報) と關聯あるものと思はれる。

上記の如く、ヒドラデンによる硫酸ェステルの分解とグルコスルファターゼによる分解との間には 多くの差異が認められるから，ヒドラデンを以てク゚ルコスルファターゼの作用機作の全般に亘り暗示

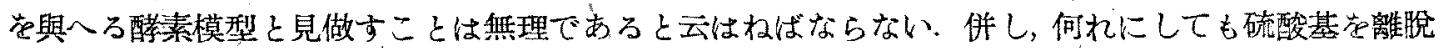
し易い狀態にする點は同一なのであろから，ヒドラヂンと硫酸エステルとの結合による硫酸基附近の 電子配置の變化を明かにし，それと硫酸基離脫との關聯が解明せられれば,スルファターゼの作用機作 喑示するであらうと思は机る。それに就ては將來の研究に待たねばならないが,現在既にヒドラヂン の作用機作に就て Langenbeckがカルボキシラーゼ模型に就てなしてるろを同程度の解釋を與へるこ とは出來ろ. 郎ち, 先に述べた㥞に,この分解の觸媒として作用する雹にはヒドラデンの少くとも一つ のアミノ基は遊離して存する要し, 叉,この反應の被解質はカルボニル基文は還元基を持つてるなけ ればならない事より，その反應機構は次の如く，先づヒドラヂン樣結合在生ずるものと思はれる. 郎ち，

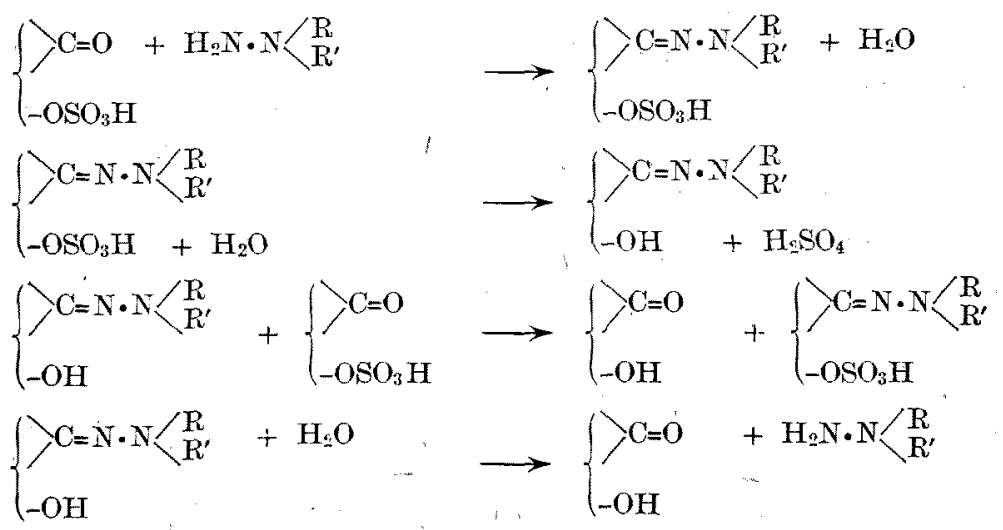

15) 左右田, 江上: 本誌, $61(1940), 683$.

16) 左右田, 江上: 本誌, $63(1942) .465$. 
かくの如く、ヒドラデンが或種の硫酸エステルの分解を促進する觸媒なることを見出し，それをス ルファターゼと比較することが筆者の研究の重點であつたが,この反應は叉糖類硫酸エステル等の硫

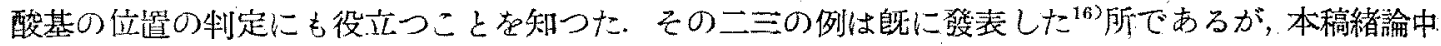
に述べた如き動植物界に存する炭水化物硫酸エステルの檏造研究 ${ }^{17} に も$ 奇與し得ると信ずる.

\section{[III ] 諸硫酸エステルとトリパフラヴィン,リヴァノール等との沈澱反應}

或種の硫酸エステルの水溶液中にトリパフラヴィン (3，6-Diamino-10-methylacridiniumchlorid)， リヴァノール (2-Äthoxy-6, 9-diaminoacridiniumlactat) の水溶液を加へると極めて稀溥な溶腹に於て

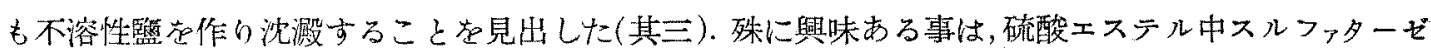
類により分解される硫酸エステルが特に稀熦溶液に於ても沈搌を與へろ事である．即ち、この沈澱性 は硫酸エステルのスルファ夕ーゼによる酵素的分解性と本行關係虑示す(其三). それ故, スルファ夕ー ゼの特哄性を決定する原子團はトリパフラヴィン,リヴァノール等を類似の構造を有するのであらうと

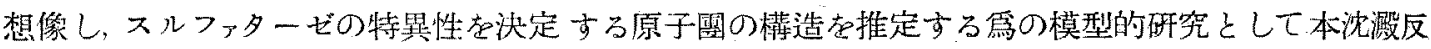

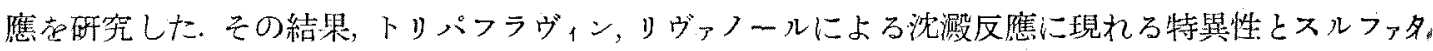
$\mathrm{H} N \stackrel{\mathrm{N}}{1+}$ 一ゼの特異性との一致は上記化合物中に存する左式の如き原子圈に由來する事を 明かにした(其六)。それ故，スルファターゼ中にも同梯な原子畻の存在が想像され

る.その後, 筆者等はスルファターゼの化學的本性の研究に當り，スルファターゼ

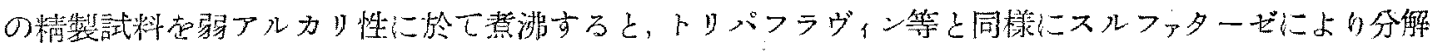

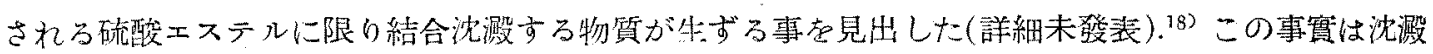
反應に現れた特異性とスルファターゼの特異性との一致は決して偶然なものではなく，惯際二の沈澱

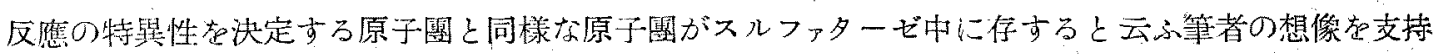

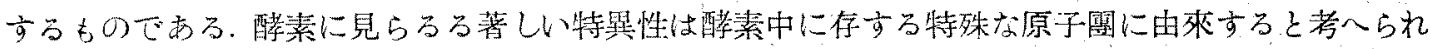
るのであるが，その栐な原子團の棈造孛模型的研究により推定した例は未だ殆に゙ない。これはその一 例と見做すことが出來らであらう。

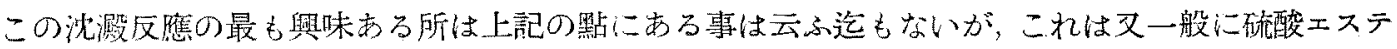
ルの研究に奇與する所も少くない，例人ば，筆者等は本反應在應用して，䚗軟骨のコンドロイチン硫

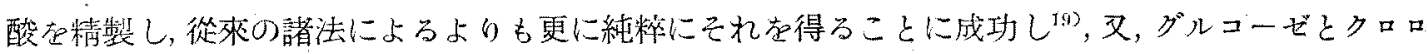
スルフォー酸よりグルコーゼ-6-モノ硫酸在合成方る場合に，之の中間生成物として先づグルコーゼ-1, 6-デ硫酸が出來，その1-位置の硫酸がとれてグルコーゼ-6-モノ硫酸となること在明かにした

上記の如くスルファターぞ模型の研究は，その完成には佾ほ今後に殘された點が少くないのである が, グルコスルファターゼ模型としてのヒドラヂン,スルファターゼの特異性に關する模型的研究とし てのトリバフラヴ、ン等による沈澱反應の何れに於ても稍重要な二三の成果な得たので竝に簡單に總 拍的教察在なした次第である。

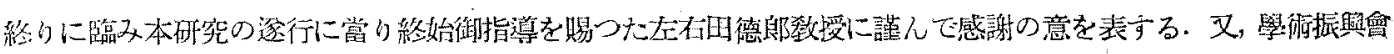

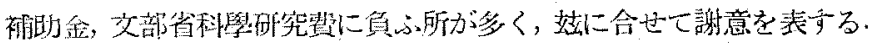

（東京蒂國大學理學部化學教室）

17) 例一ば, 江上, 内九: 本誌, 63(1942), 207.

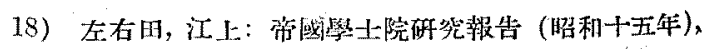

1940, 122. 19) 左右田, 江上, 堀米: 本誌, $61(1940), 43$. 